\title{
CONFLICT RESOLUTION: THE DYNAMICS OF AGRARIAN CONFLICT SOLUTION BETWEEN HARJOKUNCARAN VILLAGERS AND TNI-AD (ARMY) IN MALANG
}

\author{
Haidar Fikri \\ Master Student of Public Administration Department, Faculty of Social Studies and Politics \\ Sebelas Maret University \\ haidarfikri@student.uns.ac.id
}

\begin{abstract}
Indonesia as state law has several problems which related to the various sector. Land is a sector where the conflict often occurs, so this problem had a very close relationship with the law. The land problems in Harjokuncaran village is not apart with farmer community life who fight for their land right.One form of resistance in Harjokuncaran village was the agrarian conflict that causing physical violence between TNI-AD (Army) and Harjokuncaran villagers. This study using social movement theory and conflict resolution, this theory was chosen to review about how to form farmers movement stage until its conflict resolution. The method used is a qualitative descriptive method as the data analysis form obtained in the field. The process to collect the data using: observation, literature study, interview, and documentation. The result showed that how the most important potential to bring up the movement as the result of complaint and disappointment faced by Harjokuncaran villagers. After the social movement occurred through this resistance, their existence had been recognized by Magelang Regency Government, therefore the government had tried as much as possible to give the best solution in order to create a peaceful life. In another word, there is a conflict resolution for this problem.
\end{abstract}

Keywords: Agraria Conflict, Conflict Resolution, Social Movement

\section{Introduction}

Conflict points to the social interaction that involve claim struggle towards resource, dominance, status, belief, preference, and other desires. It is clear that unlimited conflict source, aims, scope space, intensity, method, the number of participants and result might be variable. In this case, conflict is a natural phenomenon in social relationship that must be as natural and harmonious as well.

There are many definitions of conflict because there are also many things to explain those events. Some definitions state that conflict is everywhere in which there is clear difference and it can be felt in certain situation that create emotion as a consequency (Kolb dan Putnam, 1992: 312). Another opinion more focuses on the phenomenon related to competitive aim like an intentional interruption with another purpose (Thomas, 1992:268). According to Thomas (1992:269), firstly, whether there is a conflict or not, it is only a matter of perception. The difference might be felt as unreal but if the difference is real and can not be felt, there must not be a conflict. The second general theme is that there is dependence among the sides (each side 
has a potential to interrupt others). Thirdly, there is obstruction, opposition, and scarcity on resource, such as money, dominance and limited prestige. This scarcity creates conflict. Baron (1990), in a comprehensive study of definition states that conflict happens if there is a disagreement between two groups that have certain social entity. Furthermore, Rahim (2001) extends the definition of conflict as an interactive process in incompatibility, opinion differences or dissonance in or among social entities.

In discussing conflict, we will see sociology specifically, namely conflict. The sociologists view social conflict as a manifestation of social relationship destruction. Talcott Parsons (1945:1) defines a conflict as an illness in society that causes society desctruction and creates dysfunctional role in society. The meaning of dysfunctional is a dominance of functionalism in which social structure is destroyed by the conflict. That case creates contacting without any consensus. Social conflict might happen to the border among the dominance spaces. There are three dominances in a system of society, namely "space of state dominance", "civil society or social collectivity", and "private sector" (Bebbington, 1997; and Luckham, 1998). Social conflict happens in each space and involves agency or structure among the dominance spaces. Furthermore, picture 1 can be seen as follows:

\section{Picture 1. Three spaces in which social conflict might happen}

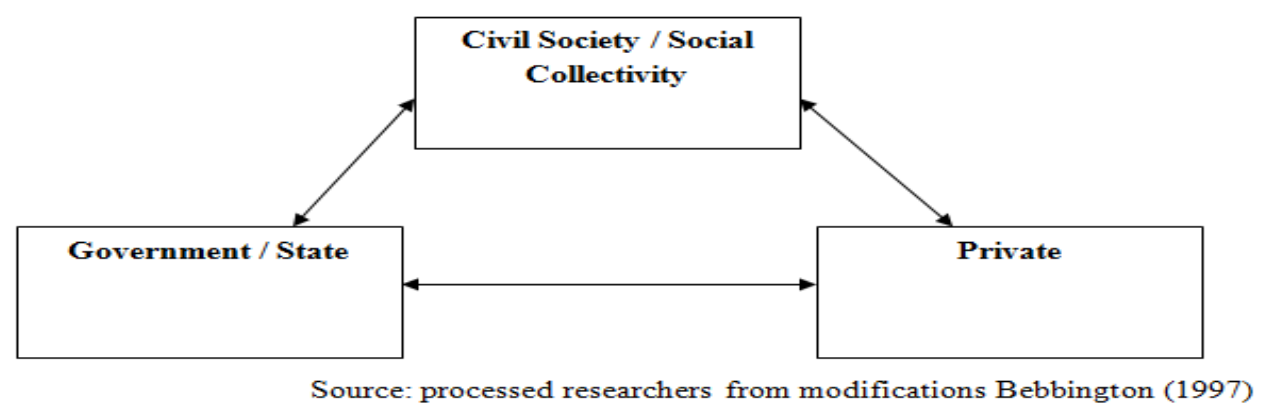

Picture 1.Three spaces in which social conflict might happen (adopted with modification by Bebbington, 1997)

By concerning the model of social conflict of dominance space by Bebbington (1997), social conflict among "dominance functionaries" can happen in three forms, namely:

(1) Civil society or social collectivity strives again the state and vice versa. Social conflict might happen as a protest upon the public policy taken by the state or the government that is supposed to be unfair and brings disadvantage to the society generally. The resistance of the 
street vendor association in Jakarta towards the eviction of the Jakarta's government is a classical sample.

(2) Social conflict is between the society and the social collectivity towards private sector and vice versa. The classical sample in this case is "bloody quarrel" that happens continuously (even until now) between local community and multi-national mining company in Papua. The same case can also be found in the tragedy of Teluk Buyat contamination that causes illness dissemination to the local residents because of tailing waste. The waste is from the activity of the gold mining by foreign private company in north Sulawesi in the early decade of 2000's.

(3) Social conflict is between the private sector and the state and vice versa. Many actions conducted by the government to supervise the policy spend social fee in the form of type conflict.

From the definition of conflict stated by Bebbington above, this article will discuss conflict between the social collectivity and the state. The main problem will be the main focus namely agrarian problem between the society and the state. Nowadays, it can be seen that there are many agrarian problems in Indonesia. The case development of agrarian could be found around 20072011. The highest number of agrarian case was in 2011 with 120 cases with land lawsuit increasement up to $342.360,43$ ha. Furthermore, the highest criminality was in 2008 with 312 people. The highest number of household head in 2011 was around 273.888 with 18 people died Ria Casmi(2014:65). The following table will explain the development of agrarian case in Indonesia:

1.1 Table of agrarian case development in 2007-2011

\begin{tabular}{llllll}
\hline YEAR & CASE & $\begin{array}{l}\text { BROAD Land } \\
\text { (ha) }\end{array}$ & $\begin{array}{l}\text { FARMER } \\
\text { CRIMINALIZATION }\end{array}$ & SEARCHED & KILL \\
\hline 2007 & 76 & 196.179 & 166 person & $24.257 \mathrm{KK}$ & 8 person \\
2008 & 63 & 49.000 & 312 person & $31.267 \mathrm{KK}$ & 6 person \\
2009 & 24 & $328.497,86$ & 84 person & $5.835 \mathrm{KK}$ & 4 person \\
2010 & 22 & 77.015 & 106 person & $21.367 \mathrm{KK}$ & 5 person \\
2011 & 120 & $342.360,43$ & 35 person & $273.888 \mathrm{KK}$ & 18 person \\
\hline
\end{tabular}

Source: Serikat Petani Indonesia (SPI), 2012

Under the leadership of Susilo Bambang Yudhoyono (2004-2014), there were 1.391 agrarian conflicts in Indonesia with the large land of 5.711.396 ha, in which there were more than 926.700 of household head felt unjustice and long conflict. Based on the sector, agrarian 
conflict in plantation field was 536, infrastructure field was 515, forestry field was 140 , farming field was 23 and naval field was only 6 (walhi.or.id).

The above case becomes the introduction of this article to explain the conflict between the social collectivity and the state in which Indonesian army and society become the main focus. According to the $14^{\text {th }}$ agrarian renewal consortium, there were some subdistrict that have land lawsuit, such as Sumbermanjing Wetan, Tirtoyudo, Gedengan, Pagak, Bantur, Sumberpucung, Kalipare, Wonosari, Ngajum, Donomulyo, Pujon, Ngantang, Kasembon and Sigosari(Suaraagraria.com). 5 of them were conflict between the Indonesian army and the residents. The early problem emerged at Harjokuncaran village. It began with the land worked by the farmers that still became the lawsuit between Harjokuncaran's residents and the Indonesian army.

Some evidences explained that the land worked by the farmers was the property right of the residents since the age of Indonesian independence that had been granted to the state. It was different with Indonesian army, they had the same right upon the half land worked by the farmers. Until now, the case has not found its solution, whether it is owned by the farmers or the Indonesian army. The residents' struggle towards the Indonesian army gave bad impacts in daily life. It was more likely to emerge the next conflict with unimportant problems.

On Friday, July $6^{\text {th }} 2012$ at 3 p.m, there was a big dispute between Harjokuncaran residents and Indonesian army to win the land (radarjakarta.com). Conflict happened again after decades in Harjokuncaran. Started from 1986, the lawsuit between the residents and Indonesian army did not find any result (batikimono.com). The land problem at Harjokuncaran village has not finished till now. The government and the residents have not found the right solution in finishing the problem related to agrarian conflict.

The main problem at Harjokuncaran village was farmer group association that expects the government to re-distribute the land to the farmers in a former land area of plantation field at Telogorejo, Harjokuncaran village. The residents demanded three reasons: firstly, the residents had obtained the heritage from the independence heroes and had had the card of contribution of regional tax payment (IPPEDA). Secondly, the dominance evidence of Indonesian army of army cooperative center was supposed to be inaccurate. Thirdly, army cooperative center was unable to manage the plantation land (case observer, 2014). The problem was the struggle of property right. The land ownership of 666 ha is now dominated by army cooperative center of regional military command V/ Brawijaya and the residents of Mulyosari and Krajan village. The residents 
proposed the suit with the ownership proof of certificate letter (letter $C$ ) owned by 900 people/ 200 family on that land (Armida S. Alisyahbana:2013).

Besides that, there was a selling transaction between the village government and the Indonesian army of regional military command V/ Brawijaya. The residents were also feeling emotional to the village government because of the former accident in which one of the farmers at Harjokuncaran village lost. Until now, there is no report of the farmer. With that case, the residents felt worried if the accident happened again.

The early land ownership was by the state with the initial name of NV. Toeren Estate Ltd, the land status was then given after Holland age surrendered to the company of C.O Telogorejo with the number of $1.640,1578$. The verponding land will be conducted six times to divide based on its large and its year with the object of landreform. It was proven with the copy of decision letter of the domestic minister no. SK. 190/DJA/1981 date 1-12-1981.

Based on the history in east Java, the residents' struggle can emerge agrarian conflict that involves Indonesian soldiers and the residents. There were 3 kinds of Indonesian soldiers; Indonesian army, Indonesian naval, and Indonesian air force. Based on the data, the most soldiers who were on conflict with the residents were from Indonesian naval, followed by Indonesian army and the last was Indonesian air force. To make it clear, see the data table about land conflict in east Java as follows;

\subsection{Land conflict that involves military in east Java}

\begin{tabular}{|c|c|c|c|c|c|c|c|}
\hline No. & $\begin{array}{l}\text { Military } \\
\text { Land } \\
\text { Conflict }\end{array}$ & $\begin{array}{l}\text { Number } \\
\text { Cases }\end{array}$ & of & $\begin{array}{l}\text { Widespread } \\
\text { Dispute }\end{array}$ & $\begin{array}{l}\text { Number } \\
\text { of Victims }\end{array}$ & \multicolumn{2}{|l|}{ Production } \\
\hline 1. & TNI-AD & 7 Kasus & & 3.294 ha & 24.800 & \multirow{3}{*}{\multicolumn{2}{|c|}{$\begin{array}{l}\text { Project housing } \\
\text { (prokimal, prokimal), } \\
\text { training facilities, } \\
\text { equipment warehouse, } \\
\text { plantation and leased for } \\
\text { military business }\end{array}$}} \\
\hline 2. & TNI-AL & 12 Kasus & & $7.744,79$ ha & 53.300 & & \\
\hline 3. & TNI-AU & 6 Kasus & & $4.355,5$ ha & 15.500 & & \\
\hline amo & & 25 Kasus & & $15.374,29$ ha & 93.600 & 5 Type of d & ignation \\
\hline
\end{tabular}

Source: R. Herlambang Perdana Wiratraman, 2004. 
The accident between the residents and the military was really terrifying. In the struggle, there was also the right violation. These problems showed that military in east Java had ruled the object plantation of landreform that must be given to the residents. The land lawsuit at Harjokuncaran village should not happen if the rule of Indonesian soldiers was obeyed in running business. Because of that, there was no reason to the military to return the asset that would be given to the residents. In the law no. 34 of 2004, article 39, states; "the soldiers are forbidden to involve in: (1) an activity as a member of a political party (2) an activity of practical politic (3) an activity of business and (4) an activity to be elected as a legislative member in general election and other political positions".

The emergence of the struggle between Harjokuncaran residents and Indonesian army was one of the basic problems that became the source of the conflict. The growing problem then developed to be conflict because there was a struggle from the sides that gained disadvantages. Agrarian problem turned up to be violence between the residents and the Indonesian army. It must be found its right solution to be a lesson in the better future to solve the problems.

The system of land management in the land sector became the main key in solving the lawsuit cases at Harjokuncaran village. The working management and the finishing method must be fixed in order to be able in solving the problems. The solution must be appropriate and fast that was supported by the various sides to realize the harmony and the pleasure for the residents of Harjokuncaran village.

\section{Research methods}

The type of research used is descriptive research with qualitative approach. The focus of this research is to look at the Conflict Resolution: The Dynamics of Agrarian Conflict Solution Between Harjokuncaran Villagers and TNI-AD (Army) in Malang.. The location of research in Malang east java with research sites is the Harjokuncaran Villagers. In data collection, researchers used observation techniques, interviews, and documentation. The methods of data analysis is using qualitative data analysis that proposed by Miles, Huberman and Saldana (2014: $33)$.

\section{Conflict and conflict resolution as a framework}

Conflict theoretical aspect has many views. Therefore, conflict can be seen from various sides. It also reviews based on its views to create broader result. In this article, the relevant study as a reference is a study of social conflict on the border among the dominance spaces. There are 
three dominances in a system of society, namely "space of state dominance", "civil society or social collectivity", and "private sector" (Bebbington, 1997; dan Luckham, 1998).

Based on this concept, it is appropriate to see how conflict happened between the farmers and the Indonesian army in Malang. The civil residents or social collectivity fights against the country and vice versa. Social conflict might happen as a residents' protest toward the government's public policy that is not supposed to be fair and generally creates disadvantages to the residents (Bebbington, 1997).

Based on the second concept, according to Coser (1967) in Oberschall (1978), social conflict is "social conflict is a struggle over values or claims to status, power, andscarce resources, in which the aims of the conflict groups are not only to gain the desired values, but also to neutralise, injure, or eliminate rivals". By concerning to the concept of social conflict, the process of social conflict will involve broad spectrum. Critical issues that frame social conflict might be found in social system (in all aspects), those are as follows;

1. Social class conflict happen between "worker class" and "employer class" in industrial relationship, or "land-owner class" and "farming worker class" in agrarian conflict.

2. Modes of production conflict happen between economical doers (production ways) of peasantry-tradisionalisme (small, subsisten, simple scale farming) and the economical doers that based on moral-economy with the profitable and exploitative accumulation.

3. Natural resources conflict is a social conflict centered on the issue of "claim dan reclaiming". The dominance of natural resource (land or water) is as an important main lawsuit. In many cases, natural resources conflict relates to agrarian conflict, in which a group struggles on their right on the land dominance claimed as a property to defeat the state, private institution or other social groups.

4. Ethnics and racial conflict shows the skin color differences and sub-cultural attribute to the skin color of the disputed sides.

5. Religious conflict happens because each side emphasizes the principal differences in their own religion.

6. Sectarian conflict is a conflict emerged by the different views or ideologies of a side. Conflict will raise up the different views among the societies (in the similar ideology).

7. Political conflict happens in a dynamics of power exercise.

8. Gender conflict happens between 2 people with different views based on the difference of gender. The sides carry out the different interests (politic, dominance, economy, and social role) and it is contrary between 2 supportive groups. 
9. Communal conflict is caused by various factors, such as identity existence of community culture and factor of sources of sustenance. Communal conflict might develop to be territorial conflict if each group is related to area identity.

10. Territorial conflict is a social conflict conducted by a community or local residents to defend their area where they live. Territorial conflict is usually found in the area of forest exertion right $(\mathrm{HPH})$, in which tradition or local community feels threatened on their life resource and social-cultural identity. It happenes when the possessor of HPH cut out the trees and the forest in the place they live and build social-cultural and social life.

11. Inter-state conflict happens between 2 countries with different interest, ideology, and economic system. It is contrary with the interests of other states.

12. In a global tendency, Inter-state conflict can develop to be regional conflict like in the era of "cold war" (Uni Soviet block vs USA block), or battle in Balkan in the last decade of 1990's, in which USA and NATO defeated Serbia.

This article will focus on the natural resource and territorial conflict. Both issues become the theoretical framework in viewing the problems between Indonesian soldiers and residents in struggling the land.

Concerning to the conflict resolution in the literature of conflict management, it gives a description of some components related to the coordination of the third sides. There is tentative consensus that states that there is no single third side which has enough political sources to solve problems related to conflict. For this reason, coordination among the mediators is important in the process of conflict management (Parry, 2004). The intervention of the third side can result a thing that is needed to take them to the court. Opening the new communication might encourage the sides to negotiate their own solution (Crocker et al, 2001).

Campbell and Hartnett defines that coordination and negotiation as a repeated process build belief, understanding and good relation (Campbell and Hartnett, 2005:7). Fisher shows that coordination and negotiation are directed to increase simultaneously and well-organized (Fisher, 2006:68). Crocker et al. defines the involvement of the coordination and negotiation of the third side must be supervised because there might be a tendency to one side only. The authority of the third side must separate from coherent politic and must build support and find resource to the strategy of conflict solution (Crocker et al,1999, pp. 57-58). Strimling explains the importance of the interaction between official diplomat and personal facilitator to contribute directly and indirectly to solve the conflict effectively (Strimling, 2006, page. 93). Supervising the 
cooperation between mediator and coordinator as a challenge is important in the mediation process (Vukovic, 2012).

According to Crocker, certain obstacles related to coalition are difficult in managing and relating the different actor interest and delegating the dominance to each mediator (Crocker et al., 2002). Strimling states that both mediators (official and non official) work to institution, government and alliance interest and responsible to the sides interest in conflict (Strimling, 2006). Ricigliano has pointed the authority among the government, the organization mediator and non-governmental organization to become a barrier to coordinate. As a government in conflict area, they must act according to national interest. Both organization mediator and nongovernmental organization must focus on the purposes and must not exploit the authority to solve the problems in mediation. The coordination among the non-governmental organizations hasbeen obstructed by the competitive funding process and low resource (Ricigliano, 2003).

Shortly, consensus and coordination of third side can become an approach that is useful to solve the conflict and support the process of systematical reconcilement. Therefore, this article will view how conflict management make the third side as a mediator in the conflict between Indonesian army and farmers. Therefore, process of conflict resolution can run well and appropriate with the purpose of reconcilement.

At last, this article will use the concept of conflict theory from Bebbington and Coser who view conflict between social collectivity (Farmers) and country (Indonesian army) and natural resource (Agriculture) and territorial.Conflict resolution is also used in this article by taking the concept from the mediation of the third side.

\section{Discussion}

\section{Conflict source}

The problem of land dominance also happened in an area that was susceptible towards agrarian conflict, especially at Harjokuncaran village. From the history, the land was owned by C.O Telogorejo in 1915. The land was planted with coffee and rubber. In 1925, the coffee plantation was taken apart and remained the rubber. It was exactly when Holland came back to Indonesia for the second time in theworld war II. In 1948's, the head of C.O Telogorejo was Cipto Utomo. In that time, the Indonesian soldiers were called "Tentara Hijrah".

The action to burn the ground was welcomed by the residents. It consisted of the residents around C.O Telogorejo. To respect the merits of the leader of "Tentara Hijrah", Mr. 
Maghenda, the residents of C.O Telogorejo used the name of Maghenda as the name of the main road from the gateway of Harjokuncaran village to the exit gateway of Sumber Asin Ringin Kembar. After burning the ground, the residents of C.O Telogorejo who used to be a planting worker and lived in a residence owned by the plantation moved to en emergency residence in the agricultural field. When the accident of burning ground happened, the obligated sides commanded to destroy the factory of C.O Telogorejo. It was burned and only remained the rubber plantation. It was then also cut down.

According to the decision letter of Indonesian agriculture minister in June $2^{\text {nd }} 1973$, No. 263/Kpts/6/1973, the former land of Telogorejo plantation was given to Army Cooperative Center of regional military command V/ Brawijaya with the large of 1.230,41 ha. The notarian certificate was made by E.Pondak in Jakarta. The letter was number 40 with the date of April $15^{\text {th }} 1980$ with the financial loss to the state. It contained that regional military command V/ Brawijaya had fully paid the financial loss with $\mathrm{Rp} 66.875 .000$, as written in the certificate of selling agreement in April $15^{\text {th }} 1980$ no. 41 and the letter of foreign monetary director of Indonesian financial department in February $2^{\text {nd }} 1987$ No. S-710/MD/1987.

The history of the land had been noted in land affair agency of Malang regency. It stated that the land requested by the residents of Harjokuncaran village of Sumbermanjing Wetan subdistrict was owned by C.O Telogorejo. The status of the land was Erpacht right upon the name of NV. Toeren Estate Ltd as follows;

\section{Status table of plantation land of Telogorejo}

\begin{tabular}{llll}
\hline No. & $\begin{array}{l}\text { Verponding } \\
\text { No. }\end{array}$ & LARGE & Date. Expires \\
\hline 1. & 708 & 350,8255 & $13-10-1956$ \\
\hline 2. & 752 & 318,5620 & $10-10-1957$ \\
\hline 3. & 926 & 283,2756 & $19-10-1962$ \\
\hline 4. & 1289 & 325,3036 & $12-10-1956$ \\
\hline 5. & 1290 & 338,7641 & $19-10-1962$ \\
\hline 6. & 1311 & 23,4270 & $12-10-1956$ \\
\hline amount & $1.640,1578$ & \\
\hline
\end{tabular}

Source: Badan Pertanahan Nasional (BPN) Malang Regency, 2015. 
From the observation above, it was the copy of the decision letter of the domestic minister no. SK. 190/DJA/1981 date 1-12-1981. Firstly, the former land of Erpacht right consisted of verponding $708,752,926,1289,1290,1311$ with the large of 1.640,1578 ha. The land was owned by the state and became the object of Landreform that could be redistributed to the workers. Secondly, it stated that half of the land with the large of 786,7700 ha, as an object of Landreform could be redistributed to the workers. Thirdly, it commanded to the governor to conduct the property right with the large of 731,9500 ha to the workers.

Based on the discussion result on the problem of the land owned by regional house of representative of Malang regency, the residents stated that they were willing to accept the excessive land owned by army cooperative center with the large of 179,948 ha. In a short time, Army Cooperative Center of regional military command V/ Brawijaya would give the land to the government of Malang regency. The measurement was conducted by team (BPN, TOPDAM V Brawijaya) with the large of 1.105,358 ha. 925,410 ha was ruled by Army Cooperative Center and the remaining land with the large of 179,948 ha was given to the Malang government. It was then given to the residents based on the agreement of army cooperative center and the village government of Ringin Kembar and Harjokuncaran. Based on the agreement, the large land was 925,410 ha. If the large land measured was too excessive, it would be given to the Malang government.

The status of property right at Harjokuncaran village was established in March $7^{\text {th }} 2003$ at Agung hall in Malang regency, based on the decision letter of the commander of the army of Brawijaya in March $3^{\text {rd }} 2004$ number: Skep/48/III/2004 about the freedom of a part of the plantation land of C.O.Telogorejo of Army Cooperative Center of regional military command V/ Brawijaya of 179,948 ha from the commander of the army to the regent of Malang. Furthermore, the submission of land management (179,948 ha) was conducted in 2005 from the government of Malang regency to the village government of Harjokuncaran (Prominent figure of Harjokuncaran village, 2012). The side of army cooperative center of regional military command $\mathrm{V} / \mathrm{Brawijaya}$ proposed the loss replacement on the investment towards the plantation on the land for about Rp 207.879.825,-

Referring to the note of land status at Harjokuncaran village, it can be concluded that the solution has not been obtained until now. It means that the land as a heritage still becomes the controversy. Thisuncertainty is as a disapoinment of Harjokuncaran residents towards the Malang government that is unable to finish this case. It is expected that the certificate can be made to get the legal right upon the land ownership. It is also expected that there will be no 
demand on the land that emerge the resistance between Harjokuncaran village and the sides of army cooperative center of regional military command V/ Brawijaya.

\section{Resistance steps}

The land owner was less attention about the safety and the prosperity of the workers in the plantation field. The owner tried to get the material profit and money based on the dominance of the land and the residents. As a result, C.O Telogorejo was the former land of Eracht right upon the name of NV. Toeren Estate Ltd (England company). The residents of the farmer group association expect that the government redistributed the land to the farmers in an area of C.O Telogorejo at Harjokuncaran village, Sumbermanjing Wetan subdistrict, Malang regency.

The land was supposed to have high economical value. Therefore, the residents of Harjokuncaran village asked the former land of C.O Telogorejo to give the land to the residents from Army Cooperative Center of regional military command V/ Brawijaya with the large of 75 ha and 179,948 ha. Based on the certificate of selling agreement in April 15 ${ }^{\text {th }} 1980$ no. 41 and the letter of foreign monetary director of Indonesian financial department in February $2^{\text {nd }} 1987$ No. S-710/MD/1987. It was actually a selling transaction by the Indonesian government and the England government in which their right had been taken over to get the agreement in finishing the financial loss. It was then paid to the owner of the coffee plantation for about Rp. 66.875.000.-.

In 1959, Mayor Wiyanto in Sumbermanjing wetan announced that all the land owners at Wonosari village were ruled under the regulation law number 8 of 1954 in October $25^{\text {th }} 1949$. The regulation stated that the residents were forbidden to plant in the field and the plantation sides could not also carry away the residents' land. After the land had been noted in Malang government, it emerged the new regulation that contained the result of agreement result in Batu in 1970. The result of the agreement stated that the plantation field that became the agriculture field and the residents' living must be given back to the plantation sides and the residents did not receive any financial loss. Therefore, the forcing break was conducted by the plantation sides in 1976. The riot happened in the village and the residents tried to report the case to the authorized institution. However, it was ignored. The village chief then gathered all the prominent figures to discuss the distribution of the land that remained about 790 ha.

Harjokuncaran village had a unique tradition in announcing the meeting. It was announced by sounding the bamboo and walking around the village. Using bamboo as a communication media was a sign to give important announcement. It also gave the information result from the 
village government. The result of the announcement was that the residents took a part in the meeting by bringing the proof of tax payment. It would be changed with the land sertificate. It had been noticed that there was a land selling transaction at Harjokuncaran village between the sides of village chief, Asman Muljono and Indonesian army of regional military command V/ Brawijaya. At the early, the residents did not know the selling transaction. But, after knowing the agreement letter, the residents realized about the accident in Batu. The residents then reported it to the government, but it obtained no result. It was known that the village government had a political affair with the Indonesian army of regional military command V/ Brawijaya. The residents then realized that the government tried to hide the case upon the land in Harjokuncaran village.

Both the residents and the Indonesian army of regional military command V/ Brawijaya had reinforcement on their right. From the side of Indonesian army, they had a right sertificate on the land selling approved by some sides. Meanwhile, the residents only had the card of contribution of regional tax payment (IPPEDA). That was a dissapoinment of the residents in the conflict between Indonesian army and Harjokuncaran's residents. Respond of the government was not fast. The residents gave borders as their right because it would be ruled by the army. The struggle of the residents happened violently. At that time, all the vehicles might not pass the roads to avoid the victims. After the day of the struggle, the stakes were cleaned. It had been tidied up by the government.

The land case in east Java can be seen through political context. The context of the problem in Malang belongs to reclaiming movement. This movement happened in the age of Soeharto era, a land case in Jenggawah, Jember. In Kalibakar, south Malang, this movement had been created when Soeharto had not declined. It was because this movement had viewed the political context upon the farmers in south Malang. Social movement would rise up when discussing the land case at Harjokuncaran village. This movement was formed by the third generation named Hadi Suyatno in 2004. The name of the association was farmer association. In the early, this movement was formed as an aspiration place to the farmer aroung the village. Related to the case happened to the residents, this movement was to against the military institution at Harjokuncaran village.

The less access about the knowledge of law made the residents realized to be supported to get their right. Law aid service $(L B H)$ was created to help the residents in the name of human right. There was also NGO that helped residents' aspiration. A good leader was also important to develop this movement to against the Indonesian soldiers. 
In the early, this movement consisted of the first generation. They were Wagiman, Mat Dollah, Poniman, Djemain, Sukiyat and Sutikno. This sixth movement age ended in the middle of their way. The report stated that these six figures were kidnapped and never returned. They had struggled to redistribute. After a few times, one of their friends was killed because of jealousy.

\section{The dynamics of conflict completion}

\section{The role of the government}

The land case at Harjokuncaran village had been handled by the National Land Agency of Malang regency. However, it had not found any good solution until now. The role of National Land Agency is not only as a mediator but also as asset legalization. Nevertheless, the different point of view will emerge the conflict to both sides that have strong arguments. The farmer association chose the way to against using physical violence.

National land agency in Malang regency had not been a decision creator because this belonged to unusual case. As usual, this case was conducted by mediation, but the land agency gave the case to the center. According to the history, there was no case in military that was brought to the court, both in the form of civil case and state affair. The role of land agency was very important. The land obtained by the residents was redistributed in Moh.Yamin age. It was because the next generation (Hadi Suyatno) had not obtained redistribution from Army Cooperative Center through land agency. This case made the residents disappointed because there were no results after conducting meeting to mediate upon the right they supposed to get.

Letter $\mathrm{C}$ or land note is an official certificate by national land agency $(B P N)$ in Malang regency. The problem of certificate was only the matter of a piece of paper. However, it had high value because it related to the person's ownership legalized by national land agency (BPN). It must be seen from the factors that encouraged because it was sometimes used for political interest. The state did not want to guarantee to the citizens' right.

Not only executive side that cared to this conflict, but legislative side also did the same. In July $9^{\text {th }} 2012$, coordination meeting was conducted in regional government in Malang regency. The meeting was attended by Malang regent and all elements of regional house of representative of Malang. The result of the meeting stated that the side of Army Cooperative Center mentioned the large land of 925,41 ha, and 179 ha was given to Malang government which then given to Harjokuncaran village. The decision of the meeting resulted that all the land was ruled by the Army Cooperative Center for 625 ha. The side of Army Cooperative Center had 
given the north sides for 75 ha to the farmers, and the south side for about 179 ha was given to Malang regency. It was then redistributed to village government of Harjokuncaran.

Regional house of representative was as a representative in government. The problem had not been clear since the meeting held again in July $12^{\text {th }} 2012$. The meeting invited the commission A of of regional house of representative of Malang regency. The stakeholder of the land were asked to attend the meeting to discuss the former land of C.O Telogorejo with large of \pm 625 ha located at Harjokuncaran village which ruled by the Army Cooperative Center of regional military command V/ Brawijaya.

The mediation was attended by some important persons such as commissioner of human right commission (Nur Kholis), Dandim 0818 Letkol A. Solihin and Army Cooperative Center of regional military command V/ Brawijaya, the head of regional house of representative (Drs. Hari Sasongko) and commission A, Malang government, and National Land Agency (BPN) and some residents' representatives. Nur Kholis explained that the second mediation was held based on the proposal of land management of regional military command V/ Brawijaya dated May $10^{\text {th }} 2013$ no: 027/PG-KT/05/2013, signed by Mr. Hadi Suyatno and Mr. Harianto. They both were the representatives of farmer group association of Harjokuncaran village. They represented 1.059 residents of Harjokuncaran. The main issue of the proposal was to manage the land with the large of 529,5 Ha in which each resident owned $\pm 5000 \mathrm{~m}^{2}$.

In the second mediation, the residents just wanted to manage the land not to own. The residents were more peaceful in this situation. It was welcomed by the Dandim 0818 well. He said," we are happy with today's condition. The residents are more peaceful because they have recognized that the land is now owned by regional military command V/ Brawijaya."

\section{The role of law aid service}

The socialization empowerment about law at Harjokuncaran village was supposed to be important. It concerned with the knowledge provisions about the understanding on the land ownership. The residents lived there with land dominance. Traditionally, the land was the heritage of the ancestors. After knowing their right, they should know the position of their right, the status of their land ownership and how the state position in giving safety towards the residents. The resistance had belonged to a conflict both physically and non-physically. As a form of resistance, the condemnation remained the residents to live in their own place. When the residents were asked to negotiate or to attend the meeting in a forum, it meant that their existence was recognized. 
Besides that, there were impacts after conflict that made the residents felt stressed. They did not have any strength except weapons such as hoe and sickle. If they had no war weapons, the existence of Indonesian army was supposed to be a terror to the residents who lived around the village. They felt that the land was the heritage from the ancestors that must be defended. Sometimes, there was somebody who had a weapon and claimed the land. It emerged the anxiety to the residents. This condition would appear again if they felt threatened. The existence of law aid service would function to accompany the residents in finishing the land case at Harjokuncaran village. It helped them to conduct mediation by collecting evidences to struggle through law way. Law aid service gave positive impacts to the residents in helping them to get their right.

\section{Conflict resolution}

Conflict is a reality in personal life and organization. Conflict cannot be avoided and must be managed. Conflict is defined as "real difference about values, hopes, process or result among the sides in practical and relational issues" (Ting-Toomey, 1994:360).

Strategy used in handling the conflict can be categorized through the way of two variables:

(1) Desires to fulfill opponent interest

(2) Desires to satisfy personal interest (Cunha et al., 2005).

The main styles of conflict management of the intersection are; mediating, avoiding, dominating, sacrificing, and respecting (Blake and Mouton, 1964; Pruitt and Rubin, 1986; Rahim and Bonoma, 1979). Rahim and Bonoma (1979) identifies each style of conflict management as a function of self and others caring level.

The definition of conflict above is true because this article discusses a conflict caused by the differences of process and value between the farmers of Harjokuncaran village and Indonesian army. Conflict model in this article was between social collectivity (farmers) and state (Indonesian soldiers) Bebbington (1997). Conflict happened in this article was resource and territorial conflict in which they tried to struggle the land as conflict source in this problem.

The solution of the conflict must be found in Malang regency. Conflict resolution becomes a choice in its finishing. According to Cunha et al., 2005, the completion must view the opponent and the owned interest that must be encountered in the same value. To finish this conflict, there must be only one way. In this article, the researcher views the conflict completion using the way of mediation conflict management of Rahim and Bonoma (1979). This article 
views the mediator in completing the conflict as stated by Parry (2004). The intervention of the third side can result a thing that is needed to take them to the court. Opening the new communication might encourage the sides to negotiate their own solution (Crocker et al, 2001). Campbell and Hartnett defines that coordination and negotiation as a repeated process build belief, understanding and good relation (Campbell and Hartnett, 2005:7). According to Kriesberg, "mediator cooperation" to describe the mediator coordination of the third sides is very important. The activity of consultation among the mediator, responsibility division in intervention process and actor selection are the key aspect of coordination (Kriesberg, 1996). Nan creates the term of "intervention coordination", it is explained that there is a strong relation among the government, non-government, and local and international institution involved in reconcilement to give maximal influences (Nan, 2003). Wallensteen and Svensson focus on how the third side involves in conflict and the reconcilement is encouraged by their own interest: "some countries will be anxious about their self related to specific conflict and proposes solution in reconcilement (Wallensteen and Svensson, 2014, p. 321).

Resolution in this case needed mediation between farmers and Indonesian soldiers through government and non-governmental institution. The government was represented by land agency (executive) and regional house of representative (legislative) and law aid service as the mediators among the sides. Therefore, this conflict found the resolution that created redistribution by the Indonesian army through national land agency in Malang regency. By this redistribution, the residents were asked to return the things that had been given by the Indonesian army. However, the sides did not care. It had been agreed that the total was 1.105,358 Ha. 925,410 Ha was given to Army Cooperative Center of regional military command V/ Brawijaya and 179,948 ha was given to the government of Malang regency. The government had given the money replacement of $\mathrm{Rp} 207.879 .825$ to Army Cooperative Center of regional military command V/ Brawijaya.

\section{Conclusion}

The farmers' struggle at Harjokuncaran village was a kind of social movement that commonly happened in society because they were not satisfied to the struggle they had done to get their right. The residents tried to get more mass as many as they could to against Indonesian army of regional military command V/ Brawijaya (Army Cooperative Center). They created a farmer association as an aspiration place to express complain. After the struggle, the government realized to handle the case at Harjokuncaran village. 
Accoding to the history, the land heritage was owned by C.O Telogorejo with political aspects. They did not know that the land had been owned by Indonesian army of regional military command V/ Brawijaya. The army side had also given the financial loss to the village government without announcing to the residents. The selling transaction between village government and Indonesian army of regional military command V/ Brawijaya made the residents angry to the village government. The residents still remembered to the accident when they had to lose a farmer and they did not the report about it. The residents were anxious if the accident might happen again.

Social movement belonged to a clash action between the residents of Harjokuncaran village and Army Cooperative Center of regional military command V/ Brawijaya. It was the expression of the disappointment of the residents. They made a banner and signpost with the writing "Land owned by Indonesian army of regional military command V/ Brawijaya". This case emerged the struggle. This potention created a movement as a form of disappointment of the residents at Harjokuncaran village. The national land agency had conducted the mediation many times to find the solution. However, the mediation was not attended by the sides of Indonesian army of regional military command $\mathrm{V} /$ Brawijaya even they had been invited many times.

The action of farmers' struggle (farmer association) was to struggle their rights upon the land right. This movement was too long. The lost of the prominent figures, Moch.Yasin and Hadi Suyatno gave the chance to the residents to reach the aims in getting their right. They worked together and influenced each others. The action was also followed by non-governmental institution namely law aid service that had given positive impacts in society. The role of the service was very important to support the residents.

Therefore, this conflict found the resolution that created redistribution by the Indonesian army through national land agency in Malang regency. By this redistribution, the residents were asked to return the things that had been given by the Indonesian army. However, the sides did not care. It had been agreed that the total was 1.105,358 Ha. 925,410 Ha was given to Army Cooperative Center of regional military command V/ Brawijaya and 179,948 ha was given to the government of Malang regency. The government had given the money replacement of Rp 207.879.825 to Army Cooperative Center of regional military command V/ Brawijaya. 


\section{References}

Baron, R.A. (1990), Organizational Conflict: Theory and Research in Conflict Management, Praeger Publishers, New York, NY.

Bebbington, A. 1997. Social Capital and Rural Intensification: Local Organizations and Islands of Sustainability in the Rural Andes. Geographic Journal, Vol. 163/2, pp. 189-197

Blake, R. and Mouton, J.S. (1964), The Managerial Grid, Gulf Publishing Co., Houston Campbell, S.P. and Hartnett, M. (2005), "A framework for improved coordination: lessons learned from the international development, peacekeeping, peacebuilding, humanitarian and conflict resolution communities", available at: http://issat.dcaf.ch/sqi/content/download/29 926/420169/file/A\%20framework\%20for\%20improved\%20coordination\%20DCAF_

Mod_5_Resource.pdf (accessed 17 March 2013).

Coser, L. (1967), Theorie sozialer Konflikte, Luchterhand, Neuwied and Berlin

Crocker, C.A., Aall, P.R. and Hampson, F.O. (1999), "The practitioner's perspectives", in Crocker, C.A., Aall, P.R. and Hampson, F.O. (Eds), Herding Cats: Multiparty Mediation in $a$

Complex World, United States Institute of Peace Press, Washington, DC, pp. 47-62.

Crocker, C.A., Hampson, F.O. and Aall, P. (2001), “A crowded stage: liabilities and benefits of multiparty mediation", International Studies Perspectives, Vol. 2 No. 1, pp. 51-67

Cunha, M., Rego, A., Cunha, R. and Cabral-Cardoso, C. (2005), Manual de Comportamento Organizacional e Gestão [Handbook of Organizatioonal behaviour and manager], RH Editora, Lisboa

Dahal, D.R. (2005), "Nepal: supporting peace processes through a systemic approach", Berghof Foundation for Peace Support, Berlin, pp. 1-37.

Fisher, R.J. (2006), “Coordination between track two and track one diplomacy in successful cases of prenegotiation", International Negotiation, Vol. 11 No. 1, pp. 65-89.

Kriesberg, L. (1996), “Coordinating intermediary peace efforts”, Negotiation Journal, Vol. 12 No. 4, pp. 341-352

Kolb, D.M. and Putnam, L.L. (1992), "The multiple faces of conflict in organizations", Journal of Organizational Behavior, Vol. 13 No. 3, pp. 311-21.

Luckham, R. 1998. Democratic Institutions and Politics in Context of Inequality, Poverty, and Conflict. IDS Working Paper No. 104. 
Nan, S.A. (2003), "Intervention coordination", available at: http://crinfo.beyondintractability.org/ essay/intervention_coordination/ (accessed 9 August 2011).

Oberschall, A. 1978. Theories of Social Conflict. Annual Review of Sociology Vol. 4, pp. 291-315

Parry, E.J. (2004), “International conflict prevention and intervention”, The RUSI Journal, Vol. 149 No. 6, pp. 56-61.

Parsons, T. (1945), "Racial and religious differences as factors in group tensions", in Bryson, L., Finkelstein, L. and MacIver, R.M. (Eds), Approaches to National Unity, Harper, New York, NY, pp. 182-99.

Pruitt, D. and Rubin, J. (1986), Social Conflict, McGraw-Hill, New York, NY

Rahim, M. and Bonoma, T. (1979), "Managing organizational conflict: a model for diagnosis and intervention", Psychological Reports, Vol. 44 No. 3c, pp. 1323-1344.

Rahim, M.A. (2001), Managing Conflict in Organizations, Quorum Books, Westport, CT.

Ricigliano, R. (2003), "Networks of effective action: implementing an integrated approach to peacebuilding", Security Dialogue, Vol. 34 No. 4, pp. 445-462.

Strimling, A. (2006), "Stepping out of the tracks: cooperation between official diplomats and private facilitators", International Negotiation, Vol. 11 No. 1, pp. 91-127

Thomas, K. (1992), “Overview of conflict and conflict management”, Journal of Organizational Behavior, Vol. 13 No. 3, pp. 263-74.

Ting-Toomey, S. (1994), "Managing intercultural conflicts effectively", in Samovar, L. and Porter, R. (Eds), Intercultural Communication: A Reader, Wadsworth, Belmont, CA, pp. 360-372.

Vukovic, S. (2012), “Coping with complexity: analyzing cooperation and coordination in multiparty mediation processes" International Negotiation, Vol. 17 No. 2, pp. 265-293 Wallensteen, P. and Svensson, I. (2014), “Talking peace: international mediation in armed conflicts", Journal of Peace Research, Vol. 51 No. 2, pp. 315-327. 